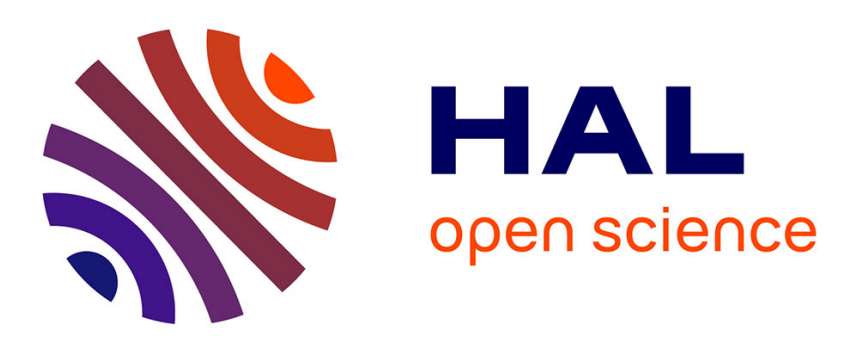

\title{
Crustal accretion at a sedimented spreading center in the Andaman Sea
}

Aurélie Jourdain, Satish Singh, Javier Escartin, Yann Klinger, K.A. Kamesh Raju, J. Mcardle

\section{- To cite this version:}

Aurélie Jourdain, Satish Singh, Javier Escartin, Yann Klinger, K.A. Kamesh Raju, et al.. Crustal accretion at a sedimented spreading center in the Andaman Sea. Geology, 2016, 44 (5), pp.351-354. 10.1130/G37537.1 . hal-02330296

\section{HAL Id: hal-02330296 \\ https://hal.science/hal-02330296}

Submitted on 19 Oct 2021

HAL is a multi-disciplinary open access archive for the deposit and dissemination of scientific research documents, whether they are published or not. The documents may come from teaching and research institutions in France or abroad, or from public or private research centers.
L'archive ouverte pluridisciplinaire HAL, est destinée au dépôt et à la diffusion de documents scientifiques de niveau recherche, publiés ou non, émanant des établissements d'enseignement et de recherche français ou étrangers, des laboratoires publics ou privés. 


\section{Crustal accretion at a sedimented spreading center in the}

\section{Andaman Sea}

3 Aurélie Jourdain ${ }^{1}$, Satish C. Singh ${ }^{1}$, Javier Escartin ${ }^{1}$, Yann Klinger ${ }^{1}$, K. A. Kamesh Raju ${ }^{2}$,

4 J. McArdle M $^{3}$

$5{ }^{1}$ Institut de Physique du Globe de Paris, Sorbonne Paris Cité, UMR7154-CNRS, 1 rue Jussieu,

678238 Paris Cedex 05, France

$7 \quad{ }^{2}$ CSIR-National Institute of Oceanography, Dona Paula, Goa 403 004, India

$8 \quad{ }^{3}$ Petroleum Geo-services, 111 Somerset Road, Singapore 238164

10 ABSTRACT

11 The combination of magmatic, tectonic, and hydrothermal processes that from the

12 oceanic crust, relatively well understood along mid-ocean spreading centers, is strongly modified

13 at sedimented spreading centers, which are still poorly understood owing to the lack of good

14 crustal images. Here we present high-resolution deep seismic reflection images across the

15 sedimented slow-spreading Andaman Sea spreading center that shows several sub-horizontal

16 sills injected within the sedimentary strata beneath the axial graben. Below this sill-sediment

17 sequence we observe reverse polarity reflections within the igneous crust, indicative of the

18 existence of axial magma lenses (AMLs) at different depths. This results in a heterogeneous

19 upper crust that incorporates metamorphosed sediments. The faults within the axial valley are

20 steeply dipping $\left(65-75^{\circ}\right)$ and are in a stair-cased pattern. Their base coincides with a shallow

21 dipping $\left(30^{\circ}\right)$ reflection, possibly defining the spreading axis morphology, controlled by the

22 AMLs. We propose that as the sill-sediment sequences move away from the axial graben, they 
23 are rotated and buried due to subsidence and faulting, forming the upper oceanic crust. The

24 Moho reflections are observed along a significant part of the profiles, allowing the

25 characterization of the whole crustal structure. We find that the upper oceanic crust is formed by

26 a combination of sill-sediment sequence, followed by a thick gabbroic lower crust with some

27 sediment along faults, with a mantle transition containing dunite lenses near the Moho.

INTRODUCTION AND SETTING

31 The oceanic crust forms at mid-ocean spreading centers by a combination of magmatic, tectonic,

32 and hydrothermal processes that are relatively well studied along both fast- and slow-spreading

33 mid-ocean ridges. However, sediments can drown spreading centers in the vicinity of continents

34 or during the early stages of continental rifting and oceanization, as observed in the Guaymas

35 Basin (Lizarralde et al., 2011; Kluesner et al, 2014), northern Juan de Fuca Ridge (Davis and

36 Becker 2002), and Mohns Ridge (Bruvoll et al., 2009). These sediments capping spreading

37 centers can significantly modify the axial thermal regime and fluid circulation, and therefore the

38 accretion processes (melt emplacement, faulting), and also the overall lithospheric structure and

39 composition. To better understand the impact of sedimentation on crustal accretion, we present

40 the first whole-crust, high-resolution multichannel seismic reflection images across the

41 sedimented Andaman Sea Spreading Center (ASSC). The unprecedented resolution of these data

42 allow us to image clearly the interactions of sedimentation and accretion, and to propose a

43 general model of lithospheric formation and whole-crust structure at sedimented mid-ocean

44 ridges. 
46 The ASSC back-arc spreading center separates the Burmese sliver plate to the northwest from

47 the Sunda plate (Eurasia) to the southwest (Fig. 1A) (Curray et al., 1979; Kamesh Raju et al.,

48 2004). It connects the northern Sagaing strike-slip fault with the southern Andaman-Nicobar and

49 Sumatra faults (Sieh and Natawidjaja, 2000), which result from strain partitioning from the

50 oblique Indian plate subduction beneath the Sunda plate (Fitch, 1972). Based on magnetic

51 anomalies on the westernmost non-sedimented segment, ASSC spreading initiated $4 \mathrm{Ma}$ ago at a

52 full rate of $16 \mathrm{~mm} / \mathrm{yr}$, speeding to $38 \mathrm{~mm} / \mathrm{yr} 2 \mathrm{Ma}$ ago (Kamesh Raju et al., 2004).

54 Most of the Andaman Sea basin is sedimented and flat lying at $3000 \mathrm{~m}$ water depth. The ASSC,

55 at the center of the basin, displays a $\sim 12 \mathrm{~km}$ wide axial valley, and an also flat-lying rift valley

56 floor at $3600 \mathrm{~m}$ water depth (Fig. 1B), infilled by sediments from the Irrawaddy river basin in

57 Myanmar (Fig. 1A) (Curray et al., 1979). This sedimented axial graben is bound by normal faults

58 and tilted fault blocks, reminiscent of the structure found at slow spreading ridges (e.g.,

59 Needham and Francheteau, 1974).

60

\section{SEISMIC DATA}

63 The seismic reflection data were acquired by Petroleum Geo-Services (PGS) in 2008 with a 6400

64 cubic inch air gun array and recorded by an 8-km long streamer with a group spacing of $12.5 \mathrm{~m}$.

65 The air gun and the streamer were towed at $8 \mathrm{~m}$ and $10 \mathrm{~m}$ below the sea surface respectively,

66 with a $25 \mathrm{~m}$ shot interval and a 9 s record length. Data were processed using a conventional time

67 migration technique, which includes swell noise removal, trace editing to remove noisy traces,

68 common midpoint binning, velocity analysis, upper mute, and stacking. Stacked data were 
69 migrated using a post-stack Kirchhoff migration technique. PGS provided the final migrated data

70 and root mean square (RMS) velocities every $1 \mathrm{~km}(160 \mathrm{CMP})$, and no pre-stack data were

71 available for our study. Here we present two N-S profiles crossing the sedimented segment of the

72 ASSC and spaced $\sim 40 \mathrm{~km}$ (Fig. 1B).

74 Figure 2 shows the interpreted seismic time sections along the two profiles that cross the rift

75 valley; un-interpreted images are shown in Figure S1. Although the profiles are N-S, $25^{\circ} \mathrm{NE}$ off

76 the orthogonal to the spreading axis, symmetry of structures on either side of the axial graben are

77 clear, and show as well as the thick sediments filling the axial valley, and numerous faults

78 penetrating down 2-2.5 s. The $7.5 \mathrm{~s}$ deep reflection is the Moho which appears intermittently

79 along both profiles.

81 In the absence of seismic refraction studies, we converted RMS velocities into interval velocities,

82 laterally smoothed to obtain a continuous velocity and seismic image. Although the RMS-

83 derived interval velocities are less accurate than those from refraction data, they provide insight

84 into crustal structure. The P-wave velocity increases from $1.6 \mathrm{~km} / \mathrm{s}$ near the seafloor to $3.0 \mathrm{~km} / \mathrm{s}$

85 at the sedimentary sequence bottom/base? (Fig. S2), which combined with the linear seismic

86 reflections suggest the presence of sedimentation layering. The alternating highly reflective and

87 transparent layers within the sedimentary column could correspond to sediment deposits

88 recording climate variability (Kluesner et al., 2014). Further below velocity increases sharply to

$894.5 \mathrm{~km} / \mathrm{s}$ within a $0.6 \mathrm{~s}$ thick zone, associated with a layer displaying numerous bright

90 reflections. Deeper and up to Moho, the reflective features are sparse but mostly steeply dipping.

91 Lacking seismic reflectors, the seismic velocity in this region is poorly constrained. 
INTERPRETATION OF SEISMIC REFLECTORS AND RESULTS

95 In this section we first focus our interpretation on the interaction between magma sills

96 emplacement sedimention, and the subsequent effects of faulting. We then address the nature of

97 the crust-mantle boundary, to provide constraints on crustal accretion process at sedimented ridges.

99 Low velocity reflectors

100 Most of the reflections in the seismic profiles are of normal polarity as that of the seafloor

101 reflection. However, both profiles display some reflections with reverse polarities (Figs.2A, 2B,

102 2C, 2D),, which suggest low velocity zones likely induced by fluids or by material with lower

103 velocity than that of the surrounding medium.

104 On-axis we observe two low velocity, revese polarity reflectors. We suggest correspond to a 105 magma bearing axial melt lens (AML), rather than other fluids such as water, as they are located

106 below the ASSC axis; such reserve polarity reflections are commonly interpreted as the present 107 of AMLs beneath fast spreading ridges (Detrick et al., 1987; Kent et al., 1993) and more recently 108 at slow-spreading (Singh et al., 2006b) ridges. The shallowest one, which is $0.8 \mathrm{~km}$ wide at $6 \mathrm{~s}$ 109 two-way travel time (TWTT) present on both profiles and we name it upper axial melt lens (U110 AML). The second deeper on, which is 2-km wide at $7.2 \mathrm{~s}$, is present only on profile PGS08-23 111 and we name it lower axial melt lens (L-AML).

112 We also observe some reverse polarity reflections off-axis, but owing to their position and

113 relatively short lateral extension, they probably correspond to fluids other than magma such as 114 water or gas circulating near faults or along sediment-sill interfaces (Fig. 2). 


\section{High velocity reflectors}

117 Within the sedimentary layers and underneath them, we observe two sets of strong and

118 discontinuous normal polarity reflections (Figs. 2A, 2B) that should correspond to high, positive

119 velocity contrasts. We interpret those that are sub-horizontal (sloping $<20^{\circ}$ ) as frozen igneous

120 bodies or sills (Figs. 2A, 2B), following similar criteria used in other studies in similar

121 environments (Trude et al. 2003; Lizarralde et al., 2011). These reflectors tilt primarily toward

122 the axis, where they can show a saucer-shape (Hansen and Cartwright, 2006).

123 Steeper reflections $\left(>20^{\circ}\right)$ can be interpreted either as highly rotated sills or as fault reflectors

124 owing to their orientation and position in the proximity of prominent and continuous faults (Figs.

$1252 \mathrm{~A}, 2 \mathrm{~B})$. We prefer to interpret them as sills because, in the sedimentary strata, faults offset

126 sediment layers and lack any reflectivity contrast (see below). Furthermore, the high reflectivity

127 of the frozen magma sills below the sedimentary sequence requires a surrounding medium that is 128 not of magmatic origin.

\section{Tectonic structures}

131 The $600 \mathrm{~m}$ deep and 12-km wide axial graben is flanked by a series of high-angle $\left(65-75^{\circ}\right)$

132 normal faults. They have a $\sim 1 \mathrm{~km}$ spacing (Figs. 2A, 2B, 3A) with a staircase pattern, dipping

133 towards the center of the basin, and are responsible for the local subsidence. These faults are

134 recent as they cut through the most recent sediments. The seismic profiles and the seafloor

135 bathymetry suggest that the nature of the graben deformation and associated faulting is similar

136 along the whole segment. 
137 Further away from the axis and central graben, shallow-dipping $\left(20-40^{\circ}\right)$ reflections at both

138 flanks of the median valley are shown in PGS08-21, and only on one flank for PGS08-23. In

139 some cases, these low-angle reflectors reach deep crustal levels and show a clear tilt of the

140 adjacent crust block. This indeed suggests a fault-related flexural rotation resulting in a shallow

141 dip of sedimentary reflectors away from the axis. This is best shown by two of the major inward-

142 dipping low angle Outer Bounding Fault North and South faults (OBF-N and OBF-S in Figs. 2A, $1432 \mathrm{~B})$.

144 A clear bounding fault buried under more recent sediments is imaged around CMP 26000-27000

145 (Fig. 2A). This fault penetrates down to $700 \mathrm{~ms}$ above the Moho, with $500 \mathrm{~ms}$ thick reflective

146 zone above the fault's lower extent (Fig. 3B). A similar, but smaller, structure is present on the

147 conjugate side to the south. On PGS08-23, these OBFs are also visible, and have some high

148 angle faults in a staircase pattern below them. These low-angle reflections may thus be akin to

149 the present-day seafloor surface of the axial graben flank. The identification of high-angle,

150 staircase patterns is increasingly difficult nearing the transform fault in the east near profile

151 PGS08-21, where the block rotation and the deformation are the highest. Locally, we observe a

152 sediment infill that has been tilted away from the axis, consistent with flexural rotation

153 associated with ridgeward normal faulting. Deep-rooted low-angle faults close to the axis rupture

154 at the seafloor. Other faults are sealed by recent sediments, forming an unconformity with the

155 tilted blocks. Hence, the faults responsible for the tilt of these blocks are not active at the present

156 time. This observation, together with the lack of a tectonic signal on the most recent sediment

157 cover, lack of fault scaprs at the seafloor away from the axis, and the concentration of seismicity

158 along the axial graben (Diehl et al., 2013), clearly demonstrate that tectonic deformation

159 concentrates along the graben. Little or no deformation occurs off-axis, and all the tectonic 
160 structures observed off-axis have been passively rafted due to oceanic accretion on-axis, where

161 we focus our analysis.

162

163 Crust-Mantle boundary

164 The Moho reflection is generally 1-5-2.5 s into the oceanic crust (Kent et al, 1994). On our data

165 it is imaged at $\sim 7.6 \mathrm{~s}$ on profile PGS08-21 and around 7.5-7.8 s on profile PGS08-23. It is

166 slightly shallower beneath the axial valley (Figs. 2A, 2B), and can be followed along a

167 significant part of the profile. If the base of the sedimentary strata is the top of the oceanic crust

168 and the Moho reflection its base, then crustal thickness would vary from 1.6 s to 2.4 s. On Profile

169 PGS08-23, between CMP 77000 and 79000, the Moho displays a complex pattern, with lens-

170 type structures (Figs. 2B, 3C); similar reflectors are observed near CMP 16000 and 25000 on

171 profile PGS08-21, and around CMP 69000 and 80000 on profile PGS08-23. Beneath the

172 spreading axis we observed a weak reflection $\sim 250 \mathrm{~ms}$ below the L-AML, which we also

173 interpret as the Moho.

174

175 DISCUSSION AND CONCLUSIONS

176

177 A combination of the interval P-wave velocity data and seismic reflection images of the full

178 crustal thickness allows us to characterize for the first time with sufficient detail the nature of the

179 whole crust formed along the axis of a sedimented spreading center.

180

$181 \quad$ Axial melt supply 
182 Multiple melt lenses have been recently reported beneath fast spreading centers (Arnulf et al.,

183 2014; Marjanovic et al., 2014), but the presence of two melt sills (U-AML and L-AML) beneath

184 a slow spreading ridge is novel as it has been difficult to image melt lens below them (Singh et

185 al., 2006b). Furthermore, the separation between the two melt sills is much larger ( 1.2 s) than

186 that observed at fast spreading ridge (0.2-0.3 s), and therefore, their roles should be different.

187 The U-AML is relatively shallow when compared to the predicted depth for AMLs for the 188 spreading rate of $3.8 \mathrm{~cm} / \mathrm{yr}$ (Chen and Morgan 1990). In the absence of any enhanced melt

189 supply to the axis, this prediction would suggest that the apparently shallow U-AML is likely a

190 transient feature at this spreading rate, but instead the presence of the reflector on the two

191 profiles 40-km apart indicates that the U-AML is instead a prevalent feature. This shallow melt

192 lens position could also be facilitated by the thick sediment layer blanketing the axial valley,

193 that likely acts as an insulating layer resulting a warmer thermal regime that could help retain a

194 melt for longer time.

195 The U-AML, which lies at the base of the sedimentary cover,is also at the intersection of the

196 median valley bounding faults, suggesting that the shallow dipping bounding faults may root at

197 the U-AML. The U-AML is also shifted $\sim 0.5 \mathrm{~km}$ northward from the axial graben on PGS08-21

198 and $\sim 1.2 \mathrm{~km}$ on PGS08-23, inducing the southern boundary fault to dip more shallowly than the

199 northern one. Such an asymmetry in faulting caused by the AML position has also been

200 suggested at the Afar rift (Grandin et al., 2009).

201 The depth of the L-AML, at $\sim 2.3 \mathrm{~s}$ below the seafloor or $\sim 4.5 \mathrm{~km}$ within the igneous crust, is

202 consistent with the prediction from lithospheric cooling models at this rpreading rate (Chen and

203 Morgan, 1990). The L-AML likely feeds the U-AML on axis, and this magmatic system bay be 
204 the source for other crustal melt sills near and off the spreading axis now frozen, although the the 205 dynamics and interactions of multiple melt lenses are not well-known.

\section{Formation of the upper crust}

208 We identify a steep gradient in P-wave velocity ranging from 3.0 to $4.5 \mathrm{~km} / \mathrm{s}$ att he base of the 209 recent sediments, clearly associated with the numerous sills observed at this depth (Fig. S2). As

210 for the Guyamas basin (Kluesner et al., 2014), the reflectors in this area show amplitude

211 whitening between sills, which could be due to fluid-expulsion and metamorphism or the

212 presence of gas (steam). The P-wave velocity in the sediments is likely to increase due to

213 compaction and fluid expulsion, and to metamorphism around sill intrusions (Aarnes et al.,

214 2011). Based on the P-wave velocity, we suggest that the upper crust is a $1.2 \mathrm{~km}$ thick velocity

215 gradient zone composed of metamorphosed sediments and sill intrusions (Fig. 4).

216 Deflation due to melt extraction in the U-AML, in addition to normal faulting along the axial

217 graben, can contribute to axial subsidence and promote the inward tilt of the sill/sediment

218 sequences. Extension concentrated at the rift valley and its flanks would thus induce the

219 development of steeply dipping faults (stair-case normal faults), possibly facilitating further

220 injection of sills in the upper sedimentary strata. High-amplitude reflections below the high-

221 velocity gradient zone are sparse, sometimes concentrating as lenses along low-angle faults. The

222 relatively higher velocity in this crustal section is indicative of magmatic accretion, but lacking

223 adequate velocity constrains we do not exclude it to be metamorphosed sill-sediment lenses

224 similar in composition to the upper crust. The former interpretation would be induced by the

225 proximity of these faults with the magma supply at the axis. The latter one would suggest high

226 variability of the metamorphic upper crustal thickness produced by locally high subsidence, and 
227 is more consistent with the presence of high velocity contrasts required to image these

228 reflections.

229 The U-AML can define the effective brittle-ductile boundary locally while it is active,

230 controlling the location of the inner bounding faults. After a certain amount of extension and

231 magmatism, a new inner bounding fault would develop inward from the existing bounding faults,

232 the older faults becoming inactive, rafted off-axis, and buried by incoming sediments. With such

233 a process, all sill-sediment sequence now present in the graben likely forms the bulk of the upper

234 part of the oceanic crust here. These results also suggest that the magmatic crustal accretion at

235 the ASSC is taken up solely by intrusive processes, consistent with the absence of clear magnetic

236 anomalies that can be attributed to eruptive units (Kamesh Raju et al., 2004), and to the lack of

237 volcanic features along the axial graben floor. Variation in magmatic supply to the AML could

238 be responsible for the two modes of faulting of the ASSC and would exclude the hypothesis of a

239 halt in the oceanic crustal accretion as suggested by Morley and Alvey, (2015). On the other

240 hand, the L-AML may locally control the rheology of the lithosphere, pinnin the root of outer

241 bounding fault, while the two melt lenses regulate activity on the outer and inner bounding

242 faults, and hence the nature of the median valley (Fig. 4).

\section{Crustal thickness and Moho transition}

245 Widespread Moho reflections allows us to constrain the nature of the lower crust and its base.

246 Lacking accurate seismic refraction velocities, we assume a P-wave velocity of $6.8 \mathrm{~km} / \mathrm{s}$ in the

247 lower crust (e.g., Lizarralde et al., 2007). This yields a lower crustal thickness of $<5.5 \mathrm{~km}$, and a

248 total crustal thickness of $<6.7 \mathrm{~km}$, overlain by $1.5 \mathrm{~km}$ of sediments, consistent with gravity-

249 derived estimations.(Morley and Alvey (2015). 
250 A complex Moho with lenses just above it could result from either dunite lenses (melt residue) or 251 gabbro lenses in the mantle-crust transition zone. Frozen melt sills below the Moho have been

252 observed beneath the Juan De Fuca Ridge (Nedimovic et al., 2005), but ASSC lenses seem to lie

253 within the Moho transition zone, and could be the residue of former L-AMLs. The complex

254 Moho transition zone with dunite-gabbro lenses observed in the Oman ophiolite (Braun and

255 Kelemen, 2002) may be a suitable analog to the complex Moho we image here. The proximity of

256 the Moho with lower melt lens creates a complex mantle transition zone, which combined with

257 the presence of multiple sills, makes the sedimented ridge a special class of ocean spreading

258 center forming unique marginal crust, but accurate seismic velocities are required to estimate the

259 magmatic supply to the axis from the relative proportion of sediment and magma and its

260 variation in depth.

261

262 ACKNOWLEDGMENTS

263

264 We would like to thank Petroleum Geo-Services (PGS) for providing the data, and Adrien Arnulf 265 and Wayne Crawford for discussions.

266

267 REFERENCES CITED

268 Aarnes, I., Fristad, K., Planke, S., and Svensen, H., 2011, The impact of host-rock composition 269 on devolatilization of sedimentary rocks during contact metamorphism around mafic sheet 270 intrusions: Geochemistry, Geophysics, Geosystems, v. 12, no. 10, Q10019, 271 doi:10.1029/2011GC003636. 
272 Arnulf, A. F., Singh S. C., and Pye J. W., 2014, Seismic evidence of a complex multi-lens melt

273 reservoir beneath the $9^{\circ} \mathrm{N}$ Overlapping Spreading Center at the East Pacific Rise:

274 Geophysical Research Letters, v. 41, p. 6109-6115.

275 Braun, M. G., and Kelemen, P.B., 2002, Dunite distribution in the Oman ophiolite: Implications

276 for melt flux through porous dunite conduits: Geochemistry, Geophysics, Geosystems, v. 3,

277 no. 11, Q8603, DOI: 10.1029/2001GC000289.

278 Buck, W. R., Lavier, L. L., and Poliakov, A. N. B., 2005, Modes of faulting at mid-ocean ridges:

279 Nature, v. 434, p. 719-723.

280 Bruvoll, V., Breivik, A. J., Mjelde, R., and Pedersen, R., B., 2009, Burial of the Mohn-

281 Knipovich seafloor spreading ridge by the Bear Island Fan: Time constraints on tectonic

282 evolution from seismic stratigraphy: Tectonics, v. 28, no. TC4001, DOI:

$283 \quad 10.1029 / 2008$ TC002396.

284 Chen, Y., and Morgan, W. J., 1990, A Nonlinear Rheology Model for Mid-Ocean Ridge Axis

285 Topography: Journal of Geophysical Research, v. 95, p. 17583-17604.

286 Curray, J. R., Moore, D. G., Lawver, L. A., Emmel, F. J., Raitt. R. W., Henry, M., and

287 Kieckhefer, R., 1979, Tectonics of Andaman Sea and Burma, in J. S. Watkins, L.

288 Montadert and P. W. Dickerson, eds, Geological and Geophysical Investigations of

289 Continental Margins edited by: American Association Petrology Geology, Memoir 29,

290 p. $189-198$.

291 Davis, E.E., and Becker, K., 2002, Observations of natural-state fluid pressures and temperatures

292 in young oceanic crust and inferences regarding hydrothermal circulation: Earth and

293 Planetary Science Letters, v. 204, p. 231-248.

294 Detrick, R. S, Buhl, P., Vera, E., Mutter, J., Orcutt, J., Madsen, J., and Brocher, T., 1987, Multi- 
channel seismic imaging of a crustal magma chamber along the East Pacific Rise: Nature, v. 326 , p. $35-41$.

297 Diehl, T., Waldhauser, F., Cochran, J. R., Kamesh Raju, K. A., Seeber, L., Schaff, D., and 298 Engdahl, 2013, Back-arc extension in the Andaman Sea: Tectonic and magmatic processes 299 imaged by high-precision teleseismic double-difference earthquake relocation: Journal of 300 Geophysical Research: Solid Earth, v. 118, p. 1-19.

301 Fitch, T. J., 1972, Plate convergence, Transcurrent Faults, and Internal Deformation 302 Adjacent to Southeast Asia and the Western Pacific: Journal of Geophysical Research, $303 \quad$ v. 77, p. $4432-4460$.

304 Grandin, R., et al., 2009, September 2005 Manda Hararo-Dabbahu rifting event Afar 305 (Ethiopia) : Constraints provided by geodetic data : Journal of Geophysical Research, v. 114, no. B08404, DOI: 10.1029/2008JB005843.

307 Hansen, D., M., and Cartwright, J., 2006, The three-dimensional geometry and growth of 308 forced folds above saucer-shaped igneous sills: Journal of Structural Geology, v. 28, p. $309 \quad 1520-1535$.

310 Kamesh Raju, K. A., Ramprasad, T., Rao, P. S., Ramalingeswara Rao, B., and Varghese, J., 3112004 , New insights into the tectonic evolution of the Andaman basin, northeast Indian 312 Ocean: Earth and Planetary Science Letters, v. 221, p. 145-162.

313 Kent, G. M., Harding, A. J., Orcutt, J. A., 1993, Distribution of Magma Beneath the East Pacific 314 Rise Between the Clipperton Transform and the $9^{\circ} 17^{\prime} \mathrm{N}$ Deval From Forward Modeling of 315 Common Depth Point Data: Journal of Geophysical Research, v. 98, p. 13945-13969.

316 Kent, G. M., Harding, A. J., Orcutt, J. A., Detrick, R. S., Mutter, J. C., Buhl, P., 1994, Uniform 317 accretion of oceanic-crust south of the Garrett transform at 14-degrees-15's on the East 
Pacific Rise: Journal of Geophysical Research-Solid Earth, v. 99, p. 9097-9116.

319 Kluesner, J., Lonsdale, P., and González-Fernández, A., 2014, Late Pleistocene cyclicity of

320 sedimentation and spreading-center structure in the Central Gulf of California: Marine

321 Geology, v. 347, p. 58-68.

322 Lizarralde, D., et al., 2007, Variation in styles of rifting in the Gulf of California: Nature, v. 448, 323 p. 466-469.

324 Lizarralde, D., Adam Soule, S., Seewald, J. S., Proskurowski, G., 2011, Carbon release by offaxis magmatism in a young sedimented spreading centre: Nature Geoscience, v. 4, p. 50-54.

326

327

328

Marjanović, M., Carbotte, S. M., Carton, H., Nedimović, M. R., Mutter J. C., and Canales, J. P., 2014, A multi-sill magma plumbing system beneath the axis of the East Pacific Rise: Nature Geoscience, v. 7, p. 825-829.

Morley, C.K., and Alvey, A., 2015, Is spreading prolonged, episodic or incipient in the Andaman Sea? Evidence from deepwater sedimentation: Journal of Asian Earth Sciences, v. 98, p. 446-456.

Nedimović, M. R., Carbotte, S. M., Harding, A. J., Detrick, R. S., Pablo Canales, J., Diebold, J. B., Kent, G. M., Tischer, M., and Babcock, M. J., 2005, Frozen magma lenses below the oceanic crust: Nature, v. 436, p. 1149-1152.

Needham, H. D., and Francheteau, J., 1974, Some characteristics of the rift valley in the Atlantic ocean near $36^{\circ} 48^{\prime}$ North: Earth and Planetary Science Letters, v. 22, p. 29-43.

Sieh, K., and Natawidjaja, D., 2000, Neotectonics of the Sumatran fault, Indonesia: Journal of Geophysical Research, v. 105, p. 28295-28326.

Singh S. C., et al., 2006b, Discovery of a magma chamber and faults beneath a Mid-Atlantic 
Ridge hydrothermal field: Nature, v. 442, p. 1029-1032.

341 Smith, W. H. F., and Sandwell, D. T., 1997, Global sea floor topography from satellite altimetry

342 and ship depth sounding: Science, v. 227, p. 1956-1962.

343 Trude, J., Cartwright, J., Davies, R., J., and Smallwood, J., 2003, New technique for dating

344 igneous sills: Geology, v. 31, no. 9, p. 813-816.

FIGURE CAPTIONS

348 Figure 1: Andaman Sea Spreading Centre: A: General map of the study area (Multibeam

349 bathymetry from Kamesh Raju et al., 2004 added to the bathymetry of Smith and Sandwell, 350 1997). ANF: Andaman Nicobar Fault, SFS: Sumatra Fault System. Red line: Andaman Sea 351 Spreading Centre (ASSC). ATF: Andaman Transform Fault. Black box indicates area shown in

352 Figure 1b. Arrows indicate the sense of the movement. B: Detailed map of the Andaman Sea 353 spreading center. Black lines indicate normal faults. The red lines indicate the seismic lines 354 shown in this study.

356 Figure 2: Seismic profiles: Interpreted seismic images A: PGS08-21 and B: PGS08-23. Time 357 here is a two-way travel time. The black dashed box refers to Figure 3A. The black boxes mark 358 the images shown in Figures 3B and 3C. CMP: Common Mid-Point. Blue horizons indicate the 359 seafloor. Active faults are indicated by black lines and inactive by dashed black lines. Sills are 360 highlighted by orange lines, possible hydrothermal deposits by dark blue lines, possible fluids by 361 light blue lines and the Moho by pink lines. The dashed pink lines indicate the top of the 362 reflective zone above the Moho. Green lines highlight some horizons in the sediments, variations 
363 in the green color is made to differentiate the sedimentary units. Red lines mark melt lenses. U-

364 AML: Upper Axial Melt Lens and L-AML: Lower Axial Melt Lens. The dark boxes mark the

365 images shown in C and D. C: Seafloor fattened image beneath valley floor for profile PGS08-21.

366 Small black boxes indicate polarity plots, from top to bottom: Polarity of the seafloor, polarity of

367 a sill, and polarity of the U-AML. D: Seismic image with L-AML flatten. Small black boxes

368 indicate polarity plots, from top to bottom: polarity of a sill near the seafloor, complex area with

369 no clear polarity, polarity of the U-AML, polarity of the L-AML.

371 Figure 3: Expanded view of seismic data: Interpretation uses the same colors as figure 2. A:

372 Depth converted seismic image in the median valley along profile PGS08-21. The velocity

373 model used is the one in supplementary Figure S2. The thickness of the faults is proportional to

374 the offset they induce. B: Time (not depth converted) blow-up of seismic image of a buried

375 bounding fault and associated sills, C: Time (not depth converted) blow-up of a reflective zone 376 above the Moho.

378 Figure 4: Crustal model of sedimented ASSC: Schematic 3D block diagram synthesizing

379 different features observed along both profiles. The block diagram differentiates un-

380 metamorphosed sedimentary layers in green, yellow and white, upper crust in light brown, lower

381 crust in brown, mantle transition zone in purple and mantle in pink. The blue line shows the

382 position of the $1.5,3.0$ and $4.5 \mathrm{~km} / \mathrm{s}$ velocity limit (from figure $\mathrm{S} 2$ ). On the right, a diagram

383 proposes the respective proportions of the sediments versus the igneous material.

385 Figure S1: Un-interpreted seismic images: A: Profile PGS08-21. B: Profile PGS08-23. 
387 Figure S2: Interval Velocity: Interval velocity as a function of time derived from the root mean

388 square velocity superimposed on the interpreted profile PGS08-21 (Fig. 2A).

(B)

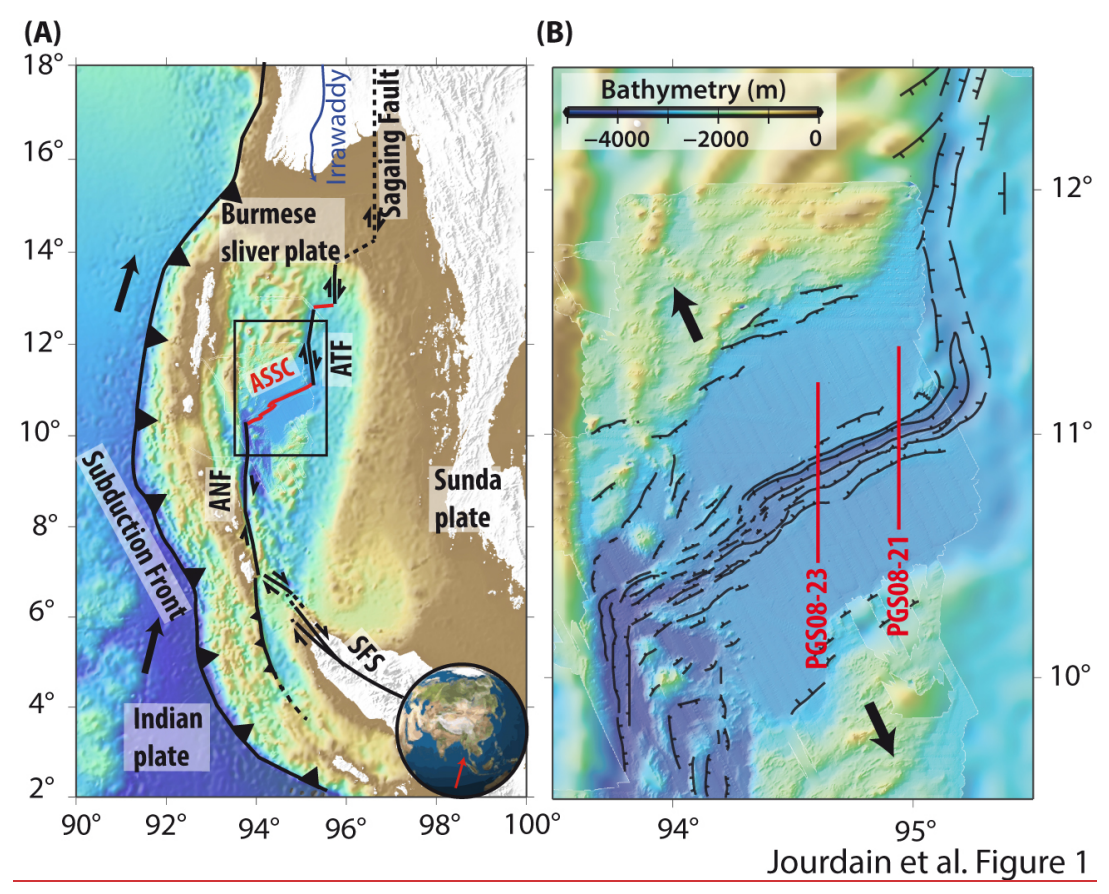



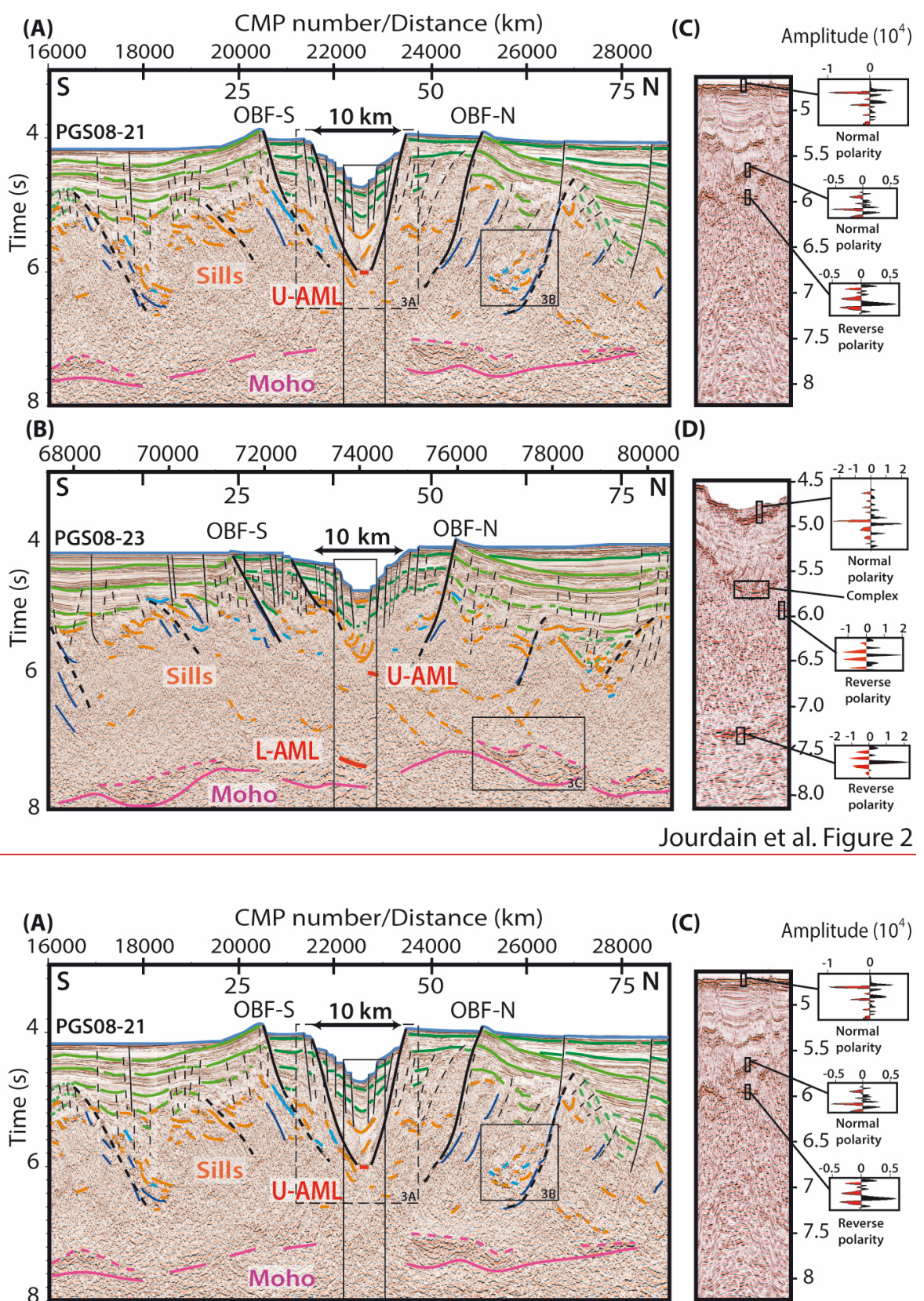

(B)

(D)

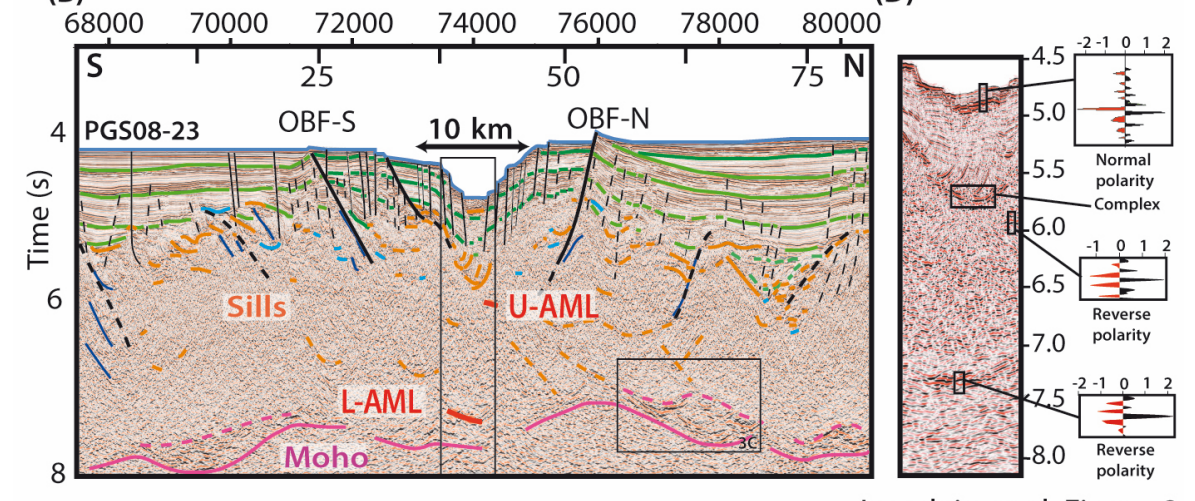




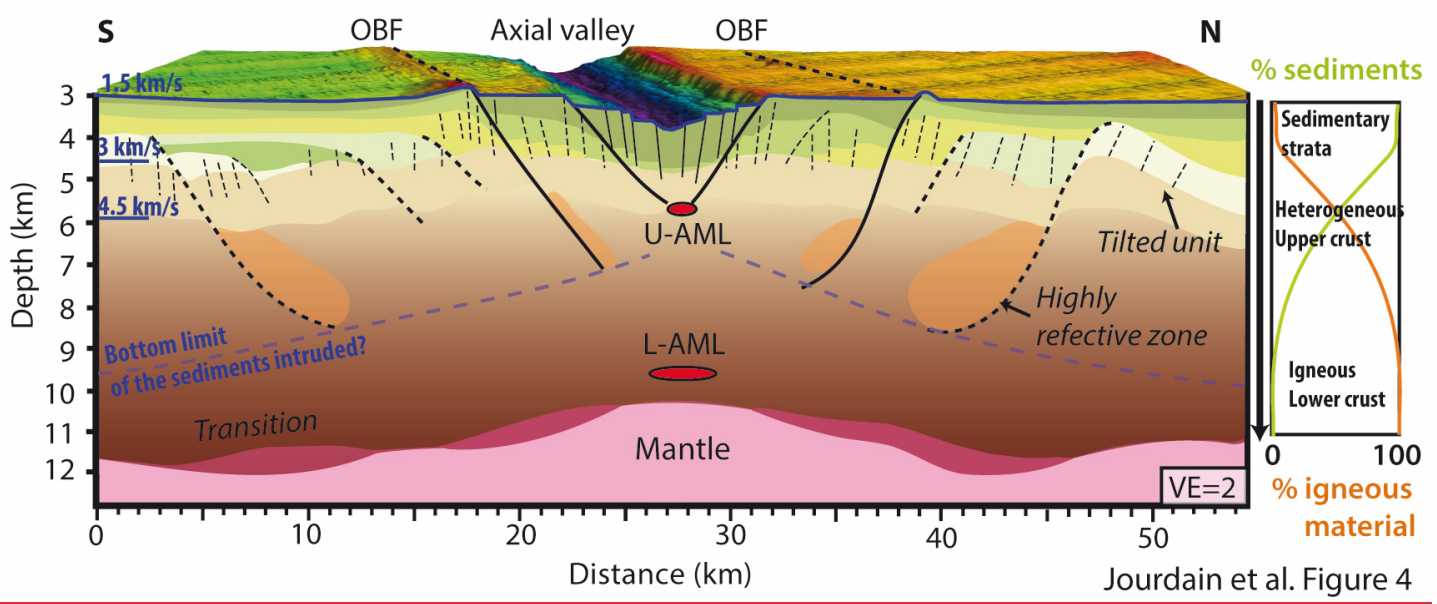

(A) $\quad \mathrm{CMP}$ number/Distance $(\mathrm{km})$

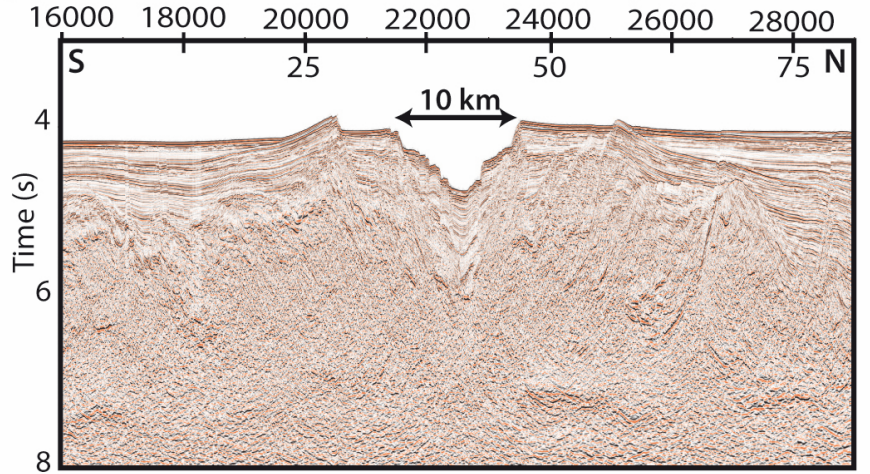

(B)

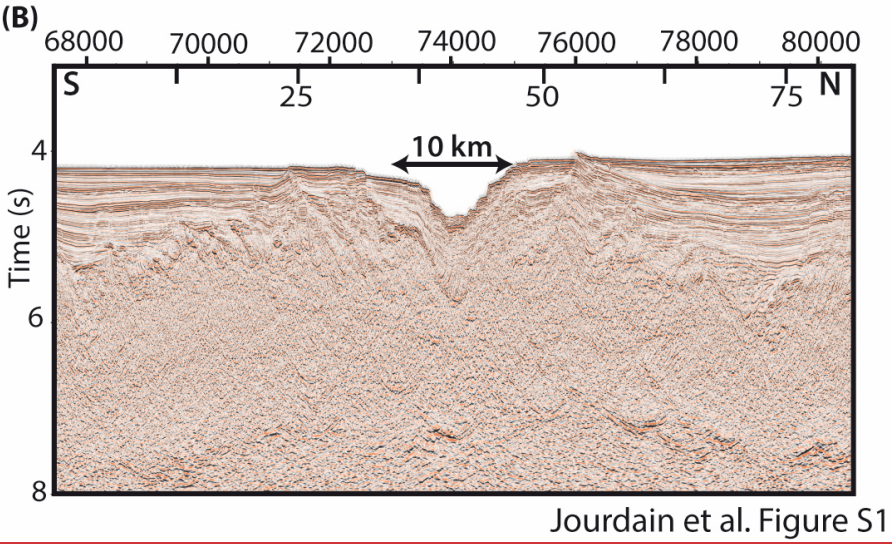




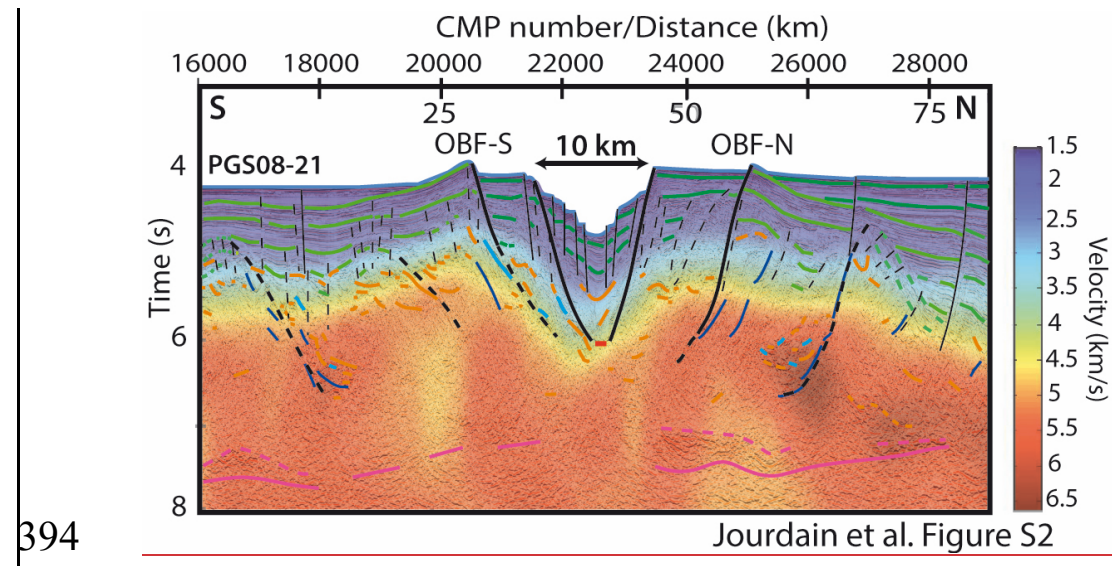

